\title{
Herbal Wine: A Review
}

\author{
Vaishali Rathi* \\ Lovely Profesional University, Phagwara, Punjab, India
}

\begin{abstract}
Wine is used as a base for medicinal preparations compounded with various herbs to treat specific diseases and disorders right from start of this century. Regular, but limited ingestion of these herbal wines tend in minimizing the need for synthetic medicines for treating various disorders by getting benefits of the herbal extracts. Numerous herbs are used to prepare herbal wine like amla, tulsi, ginger, aloe vera, tea, peppermint, and lemongrass; where either the herb is used solely as substrate or combinations of herbs are used or fruit juice is used as substrate (orange or apple juice). The combinations gave a novel product with better qualities, increased acceptability and wider applications. So, such fortifications need to be explored for developing products that could be included in the realm of health-specific products. They need to be explored more to open new doors in herbal wine industry.
\end{abstract}

Keywords: Wine; Herbal wine; Herbs; Health benefits; Extraction

\section{Introduction}

Wine comes under category of one of the fermented foods. It is stated that wine is the most ancient and most established fermented product. Right from the ancient era, the wine is produced from grapes, by fermenting the grapes to a specific duration of time, ageing them in oak barrels followed by storage in wood barrels covered with leather cloth. Grape juice is fermented with variety of yeast with subsequent ageing process yields alcoholic fruit wine. Different fruits like apple, apricot, kiwi, strawberry etc. are converted through yeast metabolic activity and changed through a process of time into wine $[1,2]$. These wines made from different fruits are made from either partial or complete fermentation process [3]. Wine contains different variety of polyphenols and other constituent such as bioactive compounds (bioactive peptides) which aids in health maintenance of consumer. During fermentation, these bioactive compounds are released into wine (aqueous ethanolic solution) making the polyphenols and bioactive components vulnerable, increasing their bioavailability, available during their absorption [4]. Wine gives the relaxation to body organs necessary for the metabolic activities like digestion and absorption of human diet [1].

\section{Basic classification of wine:}

\section{Classified to 4 major categories as}

Table wine: It includes the most popular and most selling wines i.e. red wine, white wine and cider (apple cider etc.) with sparkling wine that has the touch and appearance of carbonated beverage.

Medicinal wine: It is having medicinal properties, usually prepared with the incorporation of herbs and medicinal plants.

Fortified wine: It is known as aromatized wine with special essence and includes vermouth which is sparkling flavoured wine either flavoured with herbs or any other flavour inducing product. The vermouth could be dry vermouth or sweet vermouth.

Fruit wine: Prepared from fruits other than grapes like apple, banana, cherry, pear, plum, pomegranate, etc.

\section{Classification of wine (on basis of fruit)}

Grape wine: Grape wine falls under category of table wine and is prepared through alcoholic fermentation by using yeast cultures and grapes (could be black or green). It basically includes red wine and white wine [5-8].

Non grape wine: Fruits are produced throughout the world depending on the climatic conditions and environmental support of the particular fruit. They are produced in surplus amount in their respective growing area and are really nutritious. Fruits are consumed worldwide and are exported-imported across the borders. During the glut period the fruits deteriorate excessively due to many obvious reasons like high temperatures, humidity, improper handling, bruising during handling and transportation, microbial contaminations, pests' rodents invasion in storage area etc. Thus they are not in position to be eaten; these semi or completely deteriorated fruits are used in wine making. These fruits not only contribute in making novel wine but also increase the waste management $[9,10]$. Non grape has been already prepared from fruits like banana, apple, kiwi, strawberry, cherry, pineapple, jackfruit, jamun, raspberry, lychee, peach, pomegranate etc. (Table 1)

\section{Herbal Wine}

Before the revolution in medicinal area and rise of modern medicines, people were treated using the herbal formulations that were derived from plants [28]. Herbal infusions are trendy in wine these days. These herbs are either in powder form or completely dry form. Herbs have many positive effects on health and overall body of the human These herbs tend to have anti-microbial; anti-cancerous properties. Herbal formulations confer the health benefit on host beyond the normal benefit. Host will be benefitted both physically and mentally These herbal infusions in alcoholic drinks and beverages have tended to lower down the hypertension and increase overall body performance [29].

Different types and cosmopolitan variety of herbs play a vital role in flavour enhancement and wine production. The herbs used in herbal wine are having more tannins, polyphenols and lower titratable acidity. Herbal extracts have surplus esters and aldehydes making it

*Corresponding author: Vaishali Rathi, Lovely Profesional University, Phagwara, Punjab, India, Tel: +919501884591; E-mail: vaishali.rathi148@gmail.com

Received July 16, 2018; Accepted July 30, 2018; Published August 03, 2018

Citation: Rathi V (2018) Herbal Wine: A Review. J Nutr Weight Loss 3: 113. doi: $10.4172 / 2475-3181.1000113$

Copyright: (c) 2018 Rathi V. This is an open-access article distributed under the terms of the Creative Commons Attribution License, which permits unrestricted use, distribution, and reproduction in any medium, provided the original author and source are credited. 


\begin{tabular}{|c|c|c|c|}
\hline Fruit (substrate) & Botanical name & Result (\%alcohol) & Reference \\
\hline Apple & Malus domestica & - & Wang et al. [5] \\
\hline Banana & Musa sapientum & $\begin{array}{c}5 \\
11.28\end{array}$ & $\begin{array}{l}\text { Akubor et al. [11] } \\
\text { Kaur and Kaur [12] }\end{array}$ \\
\hline Black raspberry & Rubus occidentalis & - & Jeong et al. [13] \\
\hline Cherry & Prunus cerasus & 10.81 & Sun et al. [14] \\
\hline Custard apple & Annona squamosa & 11.90 & Jagtap and Bapat [10] \\
\hline Elder berry & Sambucus nigra & 13.20 & Schmitzer et al. [15] \\
\hline Guava & Psidium guajava & 8.3 & Sevda and Rodrigues [16] \\
\hline Jamun & Syzgium cumini & $\begin{array}{c}6 \\
9.9-11.8\end{array}$ & $\begin{array}{c}\text { Chowdhury and Ray [17] } \\
\text { Joshi et al. [18] }\end{array}$ \\
\hline Kiwi & Actinidia delicious & 13.5 & Soufleros et al. [19] \\
\hline Lychee & Litchi chinensis & 12.42 & Alves et al. [20] \\
\hline Mango & Mangifera indica & 8.5 & Reddy and Reddy [21] \\
\hline Orange & Citrus sinensis & 90.38 & Selli et al. [22] \\
\hline Papaya & Carica papaya & 55.23 & Lee et al. [23] \\
\hline Peach & Prunus persica & 13.9 & Davidović et al. [24] \\
\hline Pineapple & Ananas comosus & 10.2 & Pino and Queris [25] \\
\hline Pomegranate & Punica granatum & 9.05 & Mena et al. [26] \\
\hline Raspberry & Rubus idaeus & 74.4 & Duarte et al. [27] \\
\hline
\end{tabular}

Table 1: Non grape wines prepared from fruits other than grapes

nutritional and medicinal. Tannins found in the herbs are astringent in nature; they have aroma enhancing and antioxidant properties. They contain hydroxyl groups and carboxyl groups to form strong complexes with proteins [30]. These are diverged to have polygamous roles like enhancers, preservatives and antioxidants. These antioxidants are found in flowers, fruits, stem, roots, bark and leaves. Many studies have shown that consuming red wine can delay ageing and is protective against many diseases [31]. Herbal wine's constituents are aromatic and helpful in maintaining the health of animals and human beings. Herbal wine has many health benefits like reduction in ovarian cancer, strengthening the bones and overall skeleton, cancer cells deteoriation, prevention of heart strokes by keeping the coronary arteries clean, elevating the lung functionality. In a nutshell these herbs can deliver good anti-microbial, anti-bacterial properties, anti-mutagenic properties [32].

\section{History of Herbal Wine}

When the contemporary medicine was not in use, herbal formulations were tried on persons to heal and for body soothing. The earliest evidence of plant additives in fermented beverages were reported in China and Middle East. Chemical analysis data of earthenware gave the proof of herbal incorporation in ancient alcoholic beverages. Also, addition of tree resin in wine was reported to protect the consumer against wine disease. Evidences of tree fragrance additives along with native species like rice, wheat and millets in the alcoholic formulation were reported in china [33,34]. Vegetable, fruits and roots-bulbs like ginger, garlic and onion were subjected to fermentation in aqueous medium thus producing herbal formulation. These ingredients are macerated mixed together, steeped and strained for extracting herbal flavours. These ingredients are still part of Egyptian wine making and tradition and are effective against common ailments like cough, common cold and fever [35]. Researchers have started to report chemical and botanical evidence like herbal concoctions in alcoholic drinks. At the same time Abydos wine, herbal drink made of native rosemary and mint mixed with thyme added to fermented emmer wheat barley beverage from Spain came into reflection [36].

\section{Flavour Extraction of Herbs}

\section{Direct extraction}

It involves initial weighing of herbs followed by putting the desired herb in the base wine and let the wine sit for several hours; allowing the complete flavour of herb to come in the base wine [37]. To increase the flavour flow from herbs in to the base wine, it is better to make fine powder of herbs. The base wine flavoured with spices or herbs could either be heated or kept at room temperature while moving forward. Wine heating is usually preferred for better mixing of flavours with base wine [38].

\section{Concentrate extract method}

Extract is prepared by placing the herbs and spices outside in a vessel and passing the base wine through that vessel till complete flavour come in the base wine [39].

\section{Maceration}

Macerating the mixtures of herbs in sherry at $60^{\circ} \mathrm{C}$ and allow it to stand for 3-4 weeks or by putting herbs and spices in solvents like ethanol (or any other solvent) and extracting the flavour out of herbs. Wine along with herbs is decanted and allowed to stand for 10 days [40].

\section{Sonication assisted or microwave assisted extraction}

This technique involves principle of maceration along with microwave or ultrasound waves to extract the herbal flavours so as to shorten the extraction time. This technique is generally applied for large scale extraction of small amount of materials [40].

\section{Infusion}

An extraction procedure where herbal material is immersed in the hot or cold liquid for a small period of duration so as to produce dilute liquid preparation $[40,41]$.

\section{Decoction}

By boiling the herbs or medicinal plant in water so that all the essence and aroma of herbs flow into the water [40]

\section{Other methods}

Involves crushing and grinding of the herbs followed by boiling them in water or putting herbs in the hot water [42] Commercially 
available flavoured wine or brandy (extracted by direct method or concentrate method) could be used to flavour the base wine [42]. The extraction is generally carried out in one or two in-sealed vessels to minimize the loss of volatiles [43].

\section{Herbs Used in Making Herbal Wine}

Herbs act as enhancer, antioxidants, preservative in wine. Herbs aids in body weight management and good cardiovascular activity. Evidences of usage of herb from Palaeolithic period are there where the herbs are subjected to steeping and straining for flavour extraction and kept for fermentation or mixing with alcoholic beverage like beer. India has rooted evidences of expertise in Ayurveda where herbs, herbal powders and liquid herbal formulations were proved effective against diseases from common ailments to fatal diseases [44]. Herbs along with liquid solutions (herbal formulations) were used for treatment of since the invasion of diseases on mother earth. Table 2 shows different types of herbs used in making herbal wine.

\section{Health Benefits of Herbal Wine}

Herbal wine prepared with incorporation of herbs possesses many health benefits. Herbs have natural anti-bacterial constituents. Most of the herbs have anti-cancerous, anti-diabetic, anti-microbial and antiinflammatory properties. Herbal wine is prepared either solely from single herb like amla, holy basil etc. or it could be prepared by adding the mixture of multiple herbs like aloe-amla and aloe-ginger wine [47] These are solely the polyphenols in wine that potentiate the growth of probiotic bacteria, inhibit non-beneficial bacteria from the human micro biota, ultimately conferring health benefits to the host [55]

\begin{tabular}{|c|c|c|c|c|c|}
\hline Name of the herb & Medicinal usage of herb & Quantity & $\begin{array}{l}\text { Parts of herb or } \\
\text { plant used }\end{array}$ & $\begin{array}{c}\text { Result } \\
\text { (\%Ethanol/Remarks) }\end{array}$ & Reference \\
\hline \multirow[t]{2}{*}{$\begin{array}{c}\text { Holy basil } \\
\text { (Oscimum sanctum) }\end{array}$} & \multirow{2}{*}{$\begin{array}{l}\text { Therapeutic properties against } \\
\text { common ailments like cold, cough, } \\
\text { chronic dysentery. Anti-cancerous, } \\
\text { anti-oxidant, anti-diabetic and good } \\
\text { gastro-intestinal effect. }\end{array}$} & $\begin{array}{l}15 \mathrm{gm} \text { herb in } 200 \\
\mathrm{ml} \text { water } \\
\text { Giving } 200 \mathrm{ml} \text { of } \\
\text { extract }\end{array}$ & $\begin{array}{l}\text { Stem , leaves of } \\
\text { holy basil }\end{array}$ & $\begin{array}{l}\text { Wine made from holy basil extract } \\
\text { received the best views for flavour } \\
\text { scored } 15 / 20\end{array}$ & Shiradhonkar et al. [41] \\
\hline & & $\begin{array}{l}\text { Leaves were boiled } \\
\text { in water }\end{array}$ & $\begin{array}{l}\text { Stem , leaves of } \\
\text { holy basil }\end{array}$ & $\begin{array}{l}\text { Wine with } 5.51 \% \text { of ethanol } \\
\text { produced }\end{array}$ & Kaur and Kaur [12] \\
\hline $\begin{array}{l}\text { Lemon grass } \\
\text { (Cymbopogon citratus) }\end{array}$ & $\begin{array}{l}\text { Medicinal properties against } \\
\text { stomach disorders, fever, anti- } \\
\text { cancerous }\end{array}$ & $\begin{array}{l}15 \mathrm{gm} \text { in } 200 \mathrm{ml} \\
\text { Giving } 200 \mathrm{ml} \text { of } \\
\text { extract }\end{array}$ & Herb itself & $\begin{array}{l}\text { Pleasent aroma, scored max. Points } \\
\qquad 16 / 20 \text { in aroma }\end{array}$ & Shiradhonkar et al. [41] \\
\hline \multirow{2}{*}{$\begin{array}{c}\text { Peppermint } \\
\text { (Menthe arvensis) }\end{array}$} & \multirow{2}{*}{$\begin{array}{l}\text { Antibacterial, antifungal, antiviral. } \\
\text { Effective against respiratory } \\
\text { congestions and common ailments } \\
\text { like cough and cold }\end{array}$} & $\begin{array}{l}10 \mathrm{gm} \text { of leaves in } \\
200 \mathrm{ml} \text { of water }\end{array}$ & Herb itself & - & (Shiradhonkar et al. [41] \\
\hline & & $\begin{array}{l}1 \%, 3 \%, 5 \%, 7 \%, 9 \% \\
\quad \text { extracts used }\end{array}$ & Herb used & - & Joshi et al. [45] \\
\hline $\begin{array}{c}\text { Ginger } \\
\text { (Zinziber officinale) }\end{array}$ & $\begin{array}{l}\text { Antioxidant, regulation of glucose } \\
\text { and lipid levels, anti-cancerous } \\
\text { and antifungal effects. Effective } \\
\text { against respiratory congestions } \\
\text { and common ailments like cough } \\
\text { and cold. }\end{array}$ & $\begin{array}{l}10 \mathrm{gm} \text { of roots } \\
\text { Cut into pieces } \\
\text { Boiled with } 200 \mathrm{ml} \\
\text { of water }\end{array}$ & Roots & - & (Shiradhonkar et al. [41] \\
\hline \multirow{4}{*}{$\begin{array}{l}\text { Indian gooseberry } \\
\quad \text { (ANOLA) } \\
\text { (Emblica officinalis) }\end{array}$} & \multirow{4}{*}{$\begin{array}{l}\text { Regulation of bowel movements, } \\
\text { effective against constipation and } \\
\text { stomach disorders. Good for eye } \\
\text { sight and hair growth. } \\
\text { Rich source of vitamin C }\end{array}$} & $100 \mathrm{gm}$ & berry & Ethanol:11.4\% & $\begin{array}{c}\text { Nandagopal and Nair } \\
{[46]}\end{array}$ \\
\hline & & $\begin{array}{l}1 \%, 3 \%, 5 \%, 7 \%, 9 \% \\
\quad \text { extracts used }\end{array}$ & Dried anola used & $9 \%$ alcohol & Joshi et al. [45] \\
\hline & & - & Whole berry & $12 \%$ alcohol & Soni et al. [47] \\
\hline & & - & berry & $\begin{array}{c}10 \% \text { alcohol } \\
\text { has highest polyphenols content. } \\
\text { Gooseberry wine was } \\
\text { better in terms of all sensory and } \\
\text { biochemical aspects, withstand all } \\
\text { quality parameters }\end{array}$ & Rana and Singh [48] \\
\hline $\begin{array}{c}\text { Aloe vera } \\
\text { (Aloe Barbadensis) }\end{array}$ & $\begin{array}{l}\text { Antibacterial, antifungal, antiviral, } \\
\text { anti-inflammatory, tissue healing } \\
\text { properties, gastro-intestinal effect, } \\
\text { anti-arthritic effect. }\end{array}$ & $\begin{array}{l}100 \mathrm{ml} \text { of aloe vera } \\
\text { juice }\end{array}$ & $\begin{array}{l}\text { Aloe leaves and } \\
\text { transparent slime }\end{array}$ & $8.52 \%$ ethanol & Trivedi et al. [49] \\
\hline $\begin{array}{c}\text { Garlic } \\
\text { (Allium Sativum) }\end{array}$ & $\begin{array}{l}\text { Effective against cardiovascular } \\
\text { disease, Alzheimer's disease, } \\
\text { hyperlipidemia and against } \\
\text { hypertension. Anticancerous, } \\
\text { antimicrobial, good dermatologic } \\
\text { applications. }\end{array}$ & $\begin{array}{l}1 \%, 3 \%, 5 \%, 7 \%, 9 \% \\
\quad \text { extracts used }\end{array}$ & $\begin{array}{l}\text { Whole garlic by } \\
\text { peeling off outer } \\
\text { skin }\end{array}$ & $\begin{array}{l}\text { Garlic wine has the highest yeast } \\
\text { growth inhibiting property }\end{array}$ & Joshi et al. [45] \\
\hline $\begin{array}{c}\text { Hops } \\
\text { (Humulus Lupulus) }\end{array}$ & $\begin{array}{l}\text { Relaxing and sleep inducing } \\
\text { activity, anti-inflammatory, against } \\
\text { menopause symptoms, anti HIV } \\
1 \text { viral activity, anti-acne activity, } \\
\text { aids in weight loss and effective in } \\
\text { elevating cardiovascular health. }\end{array}$ & $\begin{array}{l}1 \%, 3 \%, 5 \%, 7 \%, 9 \% \\
\quad \text { extracts used }\end{array}$ & $\begin{array}{l}\text { By boiling the } \\
\text { female flowers } \\
\text { within apple wine so } \\
\text { that flavour come in } \\
\text { wine at } 50-55^{\circ} \mathrm{C}\end{array}$ & - & Joshi et al. [45] \\
\hline
\end{tabular}




\begin{tabular}{|c|c|c|c|c|c|}
\hline \multirow[b]{2}{*}{$\begin{array}{c}\text { Purple sweet potato } \\
\text { (Ipomoeo batatas) } \\
\text { blending with } 18 \text { different } \\
\text { herbs }\end{array}$} & \multirow[b]{2}{*}{$\begin{array}{l}\text { Rich in anthocyanin and possess } \\
\text { anti-oxidant activity. }\end{array}$} & \multirow[b]{2}{*}{$100 \mathrm{gm}$} & \multirow[b]{2}{*}{$\begin{array}{l}\text { Root of purple } \\
\text { sweet potato used } \\
\text { and all the herbs } \\
\text { were used as } \\
\text { powder }\end{array}$} & \multirow[b]{2}{*}{$\begin{array}{l}\text { Ethanol : } 8.61 \% \\
\text { Wine has the medicinal flavour } \\
\text { and dark colour was attractive. The } \\
\text { wine is rich in antioxidants such } \\
\text { as anthocyanin and phenols and } \\
\text { possesses remedies for common } \\
\text { ailments like cold, cough, skin } \\
\text { diseases and dysentery. }\end{array}$} & \multirow[b]{2}{*}{ Panda et al. [50] } \\
\hline & & & & & \\
\hline $\begin{array}{c}\text { Tea } \\
\text { (Camellia sinensis) }\end{array}$ & $\begin{array}{l}\text { Rich in polyphenols and astringent } \\
\text { compounds like flavonoids that } \\
\text { aids in protection against common } \\
\text { ailments like cough, cold and fever. } \\
\text { Anti-cancerous and anti-ageing } \\
\text { property. }\end{array}$ & $4 \mathrm{gm}$ & Tea extract used & $\begin{array}{l}8.82 \% \text { alcohol and wine possessed } \\
\text { antimicrobial activity against E.coli, } \\
\text { enterococcus faecalis }\end{array}$ & Kumar et al. [51] \\
\hline $\begin{array}{c}\text { Hibiscus petal } \\
\text { (Hibiscus rosa sinensis) }\end{array}$ & $\begin{array}{l}\text { Antifertility, wound healing, anti- } \\
\text { depressent, anti-oxidant and anti- } \\
\text { diabeteic activity. }\end{array}$ & - & $\begin{array}{l}\text { Dried crushed } \\
\text { flowers petals }\end{array}$ & $\begin{array}{l}\text { Ethanol: } 11.50 \% \\
\text { MTCC no. } 178 \text { was found most } \\
\text { potent of all the produced wine. }\end{array}$ & Tiwari et al. [52] \\
\hline $\begin{array}{c}\text { Blue water lily } \\
\text { (Nymphaea lotus) } \\
\text { used with cassava } \\
\text { starch }\end{array}$ & $\begin{array}{l}\text { Used for dysentery and dyspepsia, } \\
\text { mainly used to treat indigestion. Its } \\
\text { leaves act as cooling medicine in } \\
\text { cutaneous diseases. Therapeutic } \\
\text { effect against liver and urinary } \\
\text { disorders along with menstrual } \\
\text { problem. }\end{array}$ & $1 \mathrm{gm}$ of dried weight & Bud and stamen & $\begin{array}{l}\text { Ethanol : } 14 \% \\
\text { Nymphea-cassava wine was the } \\
\text { best among all the wines prepared } \\
\text { combinations and had the most anti- } \\
\text { oxidative properties. Good DPPH } \\
\text { activity and TPC were detected from } \\
\text { herbal wines prepared from the bud } \\
\text { of Nymphaea lotus. }\end{array}$ & Amornpitak et al. [53] \\
\hline $\begin{array}{l}\text { Wild berries } \\
\text { Emblica officianalis } \\
\text { Berberis lyceum; } \\
\text { Pyrus pashia; Actinidia } \\
\text { delisiosa; Syzigium } \\
\text { zambos; Prunus } \\
\text { cerasoidus; Rubus } \\
\text { ellipticus; Cratagus } \\
\text { spiecies; Citrus karne }\end{array}$ & $\begin{array}{l}\text { When ingested in small } \\
\text { concentrations they show positive } \\
\text { results. Possessed effects of } \\
\text { antifertility, wound healing, anti- } \\
\text { depressent, anti-oxidant and } \\
\text { anti-diabeteic activity. Reduced } \\
\text { increased kapha and pittha, helpful } \\
\text { in conception by preparing and } \\
\text { strengthening uterus. Effective } \\
\text { dermatological properties. }\end{array}$ & $1 \mathrm{~kg}$ & Berries used & $\begin{array}{c}\text { Wine prepared from Emblica } \\
\text { officianalis has highest amount } \\
\text { of polyphenols measured as total } \\
\text { phenol count. } \\
\text { Wine prepared from Emblica and } \\
\text { Prunus cerasoidus had } \\
\text { shown the best results among all } \\
\text { herbal wines prepared }\end{array}$ & Rana and Singh [48] \\
\hline \multicolumn{6}{|c|}{ Base wine used as juice (orange juice, apple must, cane juice etc.) } \\
\hline $\begin{array}{l}\text { Holy basil, Lemon grass, } \\
\text { Peppermint, Ginger } \\
\text { (Supplemented with } \\
\text { orange juice) }\end{array}$ & $\begin{array}{l}\text { Antioxidant, regulation of glucose } \\
\text { and lipid levels, anti-cancerous } \\
\text { and antifungal effects. Effective } \\
\text { against respiratory congestions } \\
\text { and common ailments like cough } \\
\text { and cold. }\end{array}$ & $15 \mathrm{gm}$ & Leaves & $\begin{array}{l}\text { Lemon grass herbal wine had } \\
\text { pleasant aroma and marked the } \\
\text { best in all sensory } \\
\text { parameters appreciation in taste. }\end{array}$ & Shiradhonkar at al. [41] \\
\hline $\begin{array}{l}\text { Aloe vera } \\
\text { (Supplemented with } \\
\text { cane sugar juice) }\end{array}$ & $\begin{array}{l}\text { Anti-microbial properties, , anti- } \\
\text { ageing, laxative effect, effect on } \\
\text { ulcers, dermatological effect and } \\
\text { other cosmetic uses }\end{array}$ & & Leaves & $\begin{array}{l}\text { The wine has antimicrobial activities } \\
\text { against foodborne pathogens and } \\
\text { it provides digestive benefits and } \\
\text { good intestinal health. }\end{array}$ & Trivedi et al. [49] \\
\hline $\begin{array}{c}\text { Tea } \\
\text { (Apple juice) }\end{array}$ & $\begin{array}{l}\text { Decreased Atherosclerosis, } \\
\text { reduced risk of } \mathrm{CHD} \text {, enhanced } \\
\text { endothelial function, anti- } \\
\text { inflammatory effect }\end{array}$ & $4 \mathrm{~g} / 100 \mathrm{ml}$ & Tea extract & $\begin{array}{l}\text { Best results with apple juice } \\
\text { concentrate as sugar source, } \\
\text { DAPH used as nitrogen source and } \\
\text { showed anti-microbial activity. }\end{array}$ & Joshi and Kumar [54] \\
\hline
\end{tabular}

Table 2: Different types of herbs used in making herbal wine

Historic evidences support addition of coriander with beer or any sweet formulation like honey, flax for traditional use in several medicinal prescriptions for treatment of piles (blood in stool).

These herbal wines have the power to reduce the blood sugar level in the body. They also control this glucose level in the body. Herbs that are subjected proved to be so effective in the body that they aids in regulating the enzyme secretion. Herbal wine have numerous properties like anti-diabetic, anti-oxidant, gastro-protectant, pain killer (analgesic), nerve soothing, good intestinal motility and cardiac activity [56-58]. Herbal wine possesses antimicrobial and antibacterial activity against food borne pathogen [59]. These herbal wine and medicines are reaching up to DNA level, and herbs have the ability to get under the nerve for protection against radiation induced chromosomal damage [60]. Table 3 illustrates all the health benefits possessed by herbal wine

\section{Herbal Wine: A Better Approach}

Homemade wines have relatively low alcohol content than the commercially available wine. Commercially available wines are having high alcohol percentage and are subjected to preservatives for storage. In homemade herbal wine formulations there is usage of neither any preservative nor additives, as these herbs are acting as preservatives so these herbal wines are not harmful for health and are acceptable 


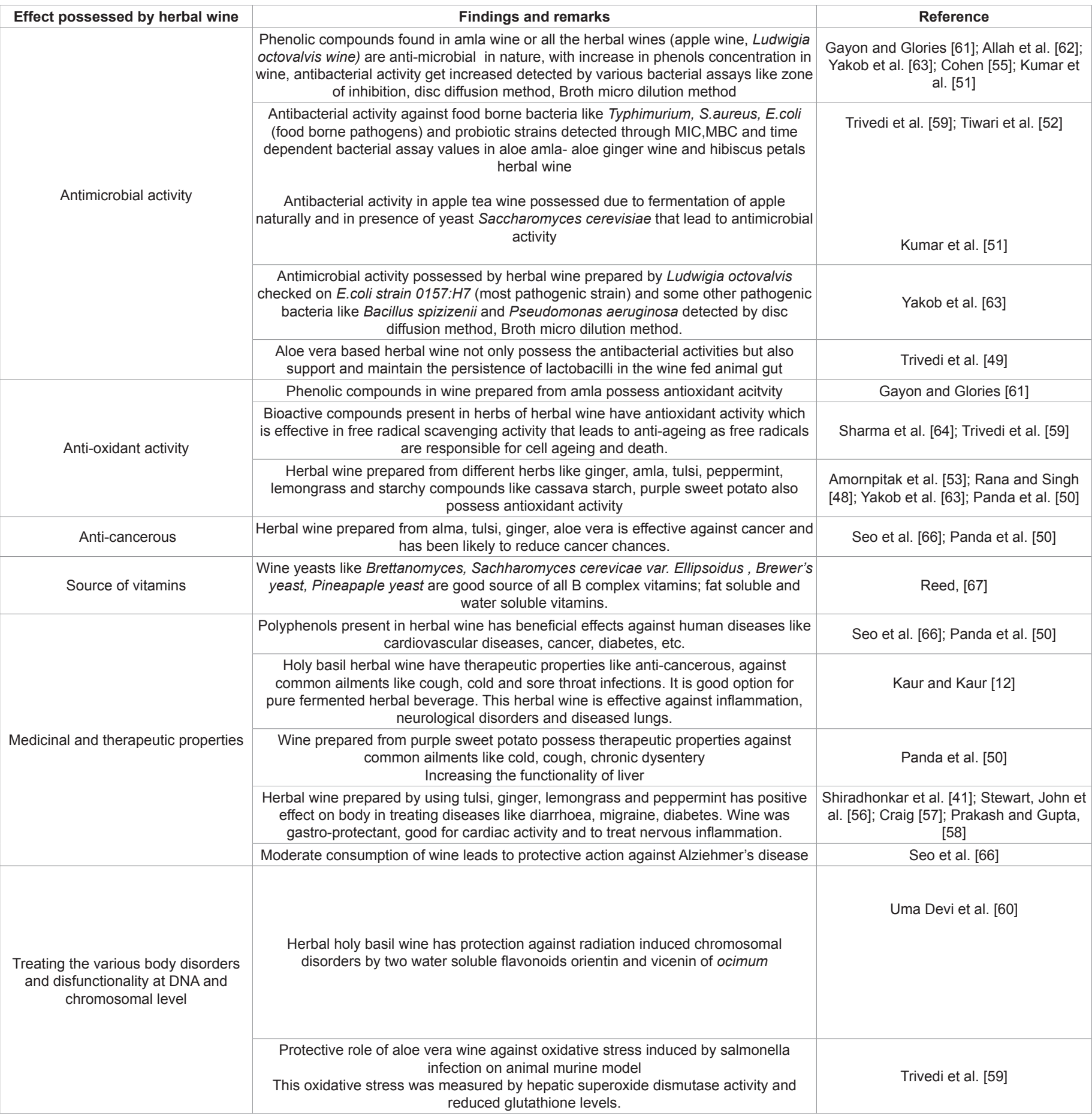

Table 3: Health benefits of herbal wine

for daily consumption. Plants contain a diverse array of metabolically active chemicals, including secondary compounds or allelochemicals (e.g., alkaloids, glycosides, phenolics, and steroids) that are beneficial to human and human health. Many metabolically active secondary compounds from plants are capable of inducing varied and profound phenotypic and genotypic changes among consumers. Sometimes, these secondary compounds in plants promote human health and survival. Human metabolic biology is intimately connected to biochemical medicine [68]. These plants parts or herbs when administered in body act round the clock from being blood purifiers, anti-microbial in nature to enhancing cardiovascular health and maintaining the body weight. Herbal interactions with human cells and enzymes works dynamically reaching up to the minute electron and thus providing benefits to human; acting as functional foods giving health benefits beyond normal.

\section{Conclusion}

In past generations the consumers and customers who would not like consumption of wine were often meant to be uncultured. But globalization, industrialization and the accompanying rapid worldwide 
access to knowledge about different types of wines, herbs and their flavours along with the respective health benefits of each herbal component added in wine, has resulted in a more knowledgeable and empowered consumer with more sophisticated understanding of product value. Although during the last decade; biotechnology has genetically mutated yeast strains that effectively and exponentially work on the substrates to yield alcohol. While food technology has developed new procedures and process to alter the already existing methodologies of wine making so as to make new product that is equally showed and accepted by customers. Now the whole production and acceptance of the wine is totally dependent on its consumer. In twenty-first century, thorough appreciation of product behaviour and consumer choice is the utmost requirement by the wineries. Herbal wine possesses all the health benefits that confer the health benefits on host beyond the normal nutrition. Health conscious consumers are always seeking the food that is not only nutritional but also confer remarkable and distinctive health benefits. Wine contains physiologically-active components that may enhance health. It should be stressed, however, that herbal wine is not a magic bullet or universal panacea for poor health alteration. It is an invasion in consumer body to alter the poor health with betterment. Herbal wine and herbal formulations provide resplendent health benefits to consumer. They act one way or another as functional foods also. They have unique properties that only give health benefits to consumer. In a nutshell, these herbal wines are novel way to step in the herbal era of wineries.

\section{References}

1. Joshi (1997) Fruit Wines. 2nd edition Directorate of Extension Education, India.

2. Siby J and Joshi VK (2003) Preparation and evaluation of cider with different sugar sources and spices extract. J Food Sci Technol 40: 673-676.

3. Joshi VK, Kumar V (2011) Importance, nutritive value, role, present status and future strategies in fruit wines in india. Bio-Processing of Foods: 39-62.

4. Shahidi F (2009) Nutraceuticals and functional foods: Whole versus processed foods. Trends Food Sci Technol 20: 376-387.

5. Wang Y, Catana F, Yang Y, Roderick R, Van Breemen RB (2002) An LC-MS method for analyzing total resveratrol in grape juice, cranberry juice, and in wine. J Agric Food Chem 50: 431-435.

6. Ortega C, Lopez R, Cacho J, Ferreira V (2001) Fast analysis of important wine volatile compounds: Development and validation of a new method based on gas chromatographic-flame ionisation detection analysis of dichloromethane microextracts. J Chromatogr A 923: 205-214.

7. Sun JP, De-zhi XI, Hui Zhang, Sen-lin Zhao (2008) Effects of grape wine aging in oak barrels on grape wine quality. Liquor-Making Science \& Technology 10:032.

8. Maitre I, Symoneaux R, Jourjon F, Mehinagic E (2010) Sensory typicality of wines: How scientists have recently dealt with this subject. Food Qual Prefer 21: 726-731.

9. Barrett Diane M, Beate $L$ (2012) Advanced preservation methods and nutrient retention in fruits and vegetables. J Sci Food Agric 92: 7-22.

10. Jagtap B, Bapat $\vee$ (2015) Phenolic composition and antioxidant capacity of wine prepared from custard apple (Annona squamosa L.) fruits. J Food Process Preserv 39: 175-182.

11. Akubor PI, Obio SO, Nwadomere KA, Obiomah E (2003) Production and quality evaluation of banana wine. Plant Foods Hum Nutr 58: 1-6.

12. Kaur A, Kaur B (2015) Production \& comparative study of holy basil wine, banana wine and date wine. Int J Sci Res 4: 638-640

13. Jeong J H, Jung H, Lee SR, Lee HJ, Hwang KT, et al. (2010) Anti-oxidant, anti-proliferative and anti-inflammatory activities of the extracts from black raspberry fruits and wine. Food Chemistry 123: 338-344.

14. Sun SY, Wen GJ, Yu PZ (2011) Evaluation of different Saccharomyces cerevisiae strains on the profile of volatile compounds and polyphenols in cherry wines. Food chemistry 127: 547-555.

15. Schmitzer V, Veberic R, Slatnar A, Stampar F (2010) Elderberry (Sambucus nigra L.) wine: A product rich in health promoting compounds. J Agric Food Chem 58: 10143-10146.

16. Sevda SB, Rodrigues L (2011) Fermentative behavior of Saccharomyces strains during guava (Psidium guajava $\mathrm{L}$ ) must fermentation and optimization of guava wine production. J Food Process Technol 2: 118.

17. Chowdhury P, Ray RC (2007) Fermentation of Jamun (Syzgium cumini L.) fruits to form red wine. ASEAN Food Journal 14: 15

18. Joshi VK, Sharma R, Girdher A, Abrol GS (2012) Effect of dilution and maturation on physico-chemical and sensory quality of jamun (Black plum) wine. Indian Journal of Natural Products and Resources 3: 222-227.

19. Soufleros EH, Pissa I, Petridis D, Lygerakis M, Mermelas K, et al. (2001). Instrumental analysis of volatile and other compounds of Greek kiwi wine: sensory evaluation and optimisation of its composition. Food Chemistry 75 487-500.

20. Alves JA, de Oliveira Lima LC, Nunes CA, Dias DR, Schwan RF (2011) Chemical, physical-chemical, and sensory characteristics of lychee (Litchi chinensis Sonn) wines. J Food Sci 76: 330-336.

21. Reddy LV, Reddy OV (2005) Production and characterization of wine from mango fruit (Mangifera indica L). World J Microbiol Biotechnol 21: 1345-1350.

22. Selli S, Canbas A, Varlet V, Kelebek H, Prost C, et al. (2007) Characterization of the most odor-active volatiles of orange wine made from a Turkish cv. Kozan (Citrus sinensis L. Osbeck). J Agric Food Chem 56: 227-234.

23. Lee PR, Yu B, Curran P, Liu SQ (2011) Effect of fusel oil addition on volatile compounds in papaya wine fermented with Williopsis saturnus var. mrakil NCYC 2251. Food Res Int 44: 1292-1298.

24. Davidović SM, Veljović MS, Pantelić MM, Baošić RM, Natić MM, et al (2013) Physicochemical, antioxidant and sensory properties of peach wine made from redhaven cultivar. J Agric Food Chem 61: 1357-1363.

25. Pino, Jorge A, Oscar Q (2010) Analysis of volatile compounds of pineapple wine using solid-phase microextraction techniques. Food Chemistry 122: 1241 1246

26. Mena P (2012). Assessment of the melatonin production in pomegranate wines. J Food Sci Technol 47: 13-18.

27. Duarte FW, Dragone G, Dias RD, et al. 2010a. Fermentative behaviour of Saccharomyces strains during microvinification of raspberry juice (Rubus idaeus L.). Int J Food Microbiol 143: 173-182

28. Jackson FL (1992) With Bitter Herbs They Shall Eat It: Chemical Ecology and the Origins of Human Diet and Medicine. American Anthropologist 94: 502-503.

29. Usman A, Jawaid A (2012) Hypertension in a young boy: An energy drink effect. BMC research notes 5: 591.

30. Ashok, Kumar P, Upadhyaya K (2012) Tannins are astringent. J Pharmacogn Phytochem 1: 45-50.

31. Rodrigo R, Miranda A, Vergara $L$ (2011) Modulation of endogenous antioxidant system by wine polyphenols in human disease. Clinica Chimica Acta, 412: 410424

32. Altenburg A, Zouboulis CC (2008) Current concepts in the treatment of recurrent aphthous stomatitis. Skin therapy let 13:1-9

33. McGovern, Patrick E, et al. (1996) Neolithic resinated wine. Nature 381: 480

34. McGovern PE, Zhang J, Tang J, Zhang Z, Hall, GR, et al. (2004) Fermented beverages of pre-and proto-historic China. Proc Natl Acad Sci USA 101 $17593-17598$.

35. McGovern PE, Mirzoian A, Gretchen R (2009) Ancient Egyptian herbal wines. Proc Natl Acad Sci 106: 7361-7366.

36. Juan (1998). La cerveza prehistórica: investigaciones arqueobotánicas experimentales. Genó: un poblado del Bronce Final en el Bajo Segre : 239-252.

37. Amerine MA (1980) The technology of wine making, USA

38. Mattick, Leonard R, Willard BR (1960) Changes in the Volatile Acids During the Baking of Sherry Wine by the Tressler Baking Process. Am J Enol Vitic 11 113-116.

39. Panesar PS, Joshi VK, Panesar R, Abrol GS (2011). Vermouth: Technology of production and quality characteristics. Advances in food and Nutrition Research, Academic Press 63: 251-283 
40. WHO guidelines (2017) Good herbal processing practices (GHPP) for herbal medicines, Switzerland.

41. Shiradhonkar R, Dukare A, Jawalekar K, Magar P, Jadhav H (2014) Fortification of wine with herbal extracts: production, evaluation and therapeutic applications of such fortified wines. IOSR J Environ Sci Toxicol Food Technol 8: 09-14.

42. Rizzo F, La fabricazione del Vermouth,Edizione Agricole, Bologna, 1957

43. Jeffs J (1970) Sherry 2nd Edition, Faber and Faber, London.

44. Jayasundar R (2010) Ayurveda: a distinctive approach to health and disease. Current Science 98: 908-914

45. Joshi VK, John S, Abrol GS (2014) Effect of addition of extracts of different herbs and spices on fermentation behaviour of apple must to prepare wine with medicinal value. Natl Acad Sci Lett 37: 541-546.

46. Nandagopal G, Nair PS (2013) Production of wine from ginger and indian gooseberry and a comparative study of them over commercial wine. American Journal of Engineering Research 3: 19-38.

47. Soni SK, Bansal N, Soni R (2009) Standardization of conditions for fermentation and maturation of wine from amla. Indian J Nat Prod Resour 8: 436-444.

48. Rana A, Singh HP (2013) Bio-utilization of wild berries for preparation of high valued herbal wines. Indian J Nat Prod Resour 4: 165-169.

49. Trivedi N, Rishi P, Soni SK (2012) Production of a herbal wine from 'Aloe vera' gel and evaluation of its effect against common food borne pathogens and probiotics. Int J food ferment technol 2: 157-166

50. Panda SK, Swain MR, Singh S, Ray RC (2013) Proximate compositions of a herbal purple sweet potato (Ipomoea batatas L.) wine. J Food Process Preserv 37: 596-604.

51. Kumar V, Joshi VK, Vyas G, Thakur NS, Sharma N (2016) Process optimization for the preparation of apple tea wine with analysis of its sensory and physicochemical characteristics and antimicrobial activity against food-borne pathogens. Nutrafoods 15: 111-121.

52. Tiwari S, Shukla S, Kishor K (2017) Production, optimization, characterization and evaluation of antimicrobial activities in Hibiscus rosa-sinensis wine. J Pharmacogn Phytochem 6: 19-26.

53. Amornpitak T, Koguchi M, Teramoto $Y$ (2012) Antioxidant activity of herbal wine made from cassava starch. World Appl Sci J 16: 874-878.

54. Joshi VK, Kumar V (2017) Influence of different sugar sources, nitrogen sources and inocula on the quality characteristics of apple tea wine. J Inst Brew 123: 268-276.
55. Cohen J, Lockshin L, Sharp B (2012) A better understanding of the structure of a wine market using the attribute of variety. International $\mathrm{J}$ of Business and Globalisation 8: 66-80

56. Stewart JJ, Wood MJ, Wood CD, Mims ME (1991) Effects of ginger on motion sickness susceptibility and gastric function. Pharmacology 42: 111-120.

57. Craig WJ (1997) Phytochemicals: guardians of our health. J Am Diet Assoc 97: 199-204

58. Prakash P, Gupta N (2005) Therapeutic uses of Ocimum sanctum Linn (Tulsi) with a note on eugenol and its pharmacological actions: A short review. Indian J Physiol Pharmacol 49: 125-131.

59. Trivedi N, Rishi P, Soni SK (2015) Antibacterial activity of prepared Aloe vera based herbal wines against common food-borne pathogens and probiotic strains. Int J of Home Science 1: 91-99.

60. Vrinda B, Devi PU (2001) Radiation protection of human lymphocyte chromosomes in vitro by orientin and vicenin. Mutat Res Genet Toxicol Environ Mutagen 498: 39-46

61. Ribéreau-Gayon P, Glories Y (1986) Phenolics in grapes and wines. Proceedings of the 6th Australian wine industry technical conference. Australian Wine Industry Technical Conference, Australia.

62. Allah AA, Ibrahium MI, Al-Atrouny AM (2011) Effect of black tea on some cariogenic bacteria. World Appl Sci J 12: 552-558.

63. Yakob, Kadum H, Shaida F, Uyub AM (2012) Antioxidant and antibacterial activity of Ludwigia octovalvis on Escherichia coli O157: H7 and some pathogenic bacteria. World Appl Sci J 16: 22-29.

64. Sharma UK, Sharma K, Sharma N, SharmaA, Singh HP, et al. (2007) Microwaveassisted efficient extraction of different parts of Hippophae rhamnoides for the comparative evaluation of antioxidant activity and quantification of its phenolic constituents by reverse-phase high-performance liquid chromatography (RPHPLC). J Agric Food Chem 56: 374-379.

65. Yen GC, Duh PD, Tsai HL (2002) Antioxidant and pro-oxidant properties of ascorbic acid and gallic acid. Food Chemistry 79: 307-313.

66. Seo MY, Chung SY, Choi WK, Seo YK, Jung SH, et al. (2009) Anti-aging effect of rice wine in cultured human fibroblasts and keratinocytes. J Biosci Bioeng, 107: 266-271.

67. Reed G (1981) Use of microbial cultures-yeast products. Food Technology 35 89-94.

68. Johns T (1990) With Bitter Herbs They Shall Eat It: Chemical Ecology and the Origins of Human Diet and Medicine Univ of Arizona Press, Tucson, Arizona 